\title{
KONSUMSI DI MASA PANDEMI COVID-19 \\ DITINJAU DARI EKONOMI MIKRO ISLAM
}

\author{
Ramadhani Irma Tripalupi \\ Fakultas Ekonomi dan Bisnis Islam, UIN Sunan Gunung Djati Bandung \\ Email: ramadhaniirmatripalupi@uinsgd.ac.id
}

\begin{abstract}
ABSTRAK
Tulisan ini bertujuan untuk mengkaji konsumsi di masa pandemi Covid-19 ditinjau dari Ekonomi Mikro Islam. Terdapat dua fokus pembahasan pada artikel ini yakni: (1) Teori konsumsi pada Ekonomi Mikro, dan (2) Konsumsi di masa pandemi Covid-19 ditinjau dari Ekonomi Mikro Islam. Pendekatan menggunakan kualitatif, metode diskriptif dan analisis eksplorasi dengan studi dokumentasi/teks berupa datadata yang terkait dan studi berbagai literatur. Simpulan artikel ini adalah bahwa konsumsi menurut Islam dapat dijelaskan melalui pendekatan-pendekatan teori konsumsi pada ekonomi mikro konvensional, perbedaannya konsumsi menurut Islam terdapat prinsip-prinsip dan batasan-batasan syariah. Konsep efisiensi dalam ekonomi konvensional adalah memaksimumkan kepuasan keinginan (want), sedangkan dalam kerangka Islam adalah memaksimumkan pemenuhan kebutuhan (need). Konsumen Muslim yang terdampak pandemi Covid-19, akan menghadapinya dengan relatif baik. Segera menyesuaikan ketika permintaannya bergeser atau berubah akibat kondisi tersebut. Karena perilaku konsumsinya telah terlatih dan terbiasa berpedoman pada tuntunan agar tidak ishraf, tidak tabdzir serta halal sehingga diridhoi Allah SWT. Sebagian konsumen tetap dapat menjalankan infaq, ditunjukkan dengan adanya ta'awun selama pandemi Covid-19, sehingga dalam kegiatan kosumsinya teraih tujuan yakni maslahah, dalam rangka mencapai tujuan yang lebih tinggi yakni kemenangan di dunia dan akhirat.
\end{abstract}

\section{KATA KUNCI}

Konsumsi, Pandemi Covid-19, dan Ekonomi Mikro Islam. 


\section{PENDAHULUAN}

Tahun 2020 merupakan tahun adanya beberapa pergeseran kebiasaan-kebiasaan masyarakat, hal ini terjadi karena dampak pandemi virus Corona Virus Diseases 19 (Covid-19) yang melanda hampir di semua negara. Penyebaran pandemi Covid-19 berawal dari wilayah daratan China pada awal tahun 2020, kemudian menjadi wabah pandemi yang menjangkiti di 214 negara dengan 3.349.786 kasus per tanggal 4 Mei 2020. Indonesia termasuk negara yang terjangkiti virus ini mulai sekira medio Maret 2020, dan sampai tanggal 22 November 2020 mencatat 493.308 kasus $^{1}$.

Negara-negara yang terjangkiti Covid-19 tersebut, terkena dampak yang tidak bisa dihindari. Pemerintah mengambil berbagai kebijakan untuk menahan tingkat penularan Covid-19 yang sangat cepat, seperti kebijakan lockdown total, karantina wilayah, Pembatasan Sosial Berskala Besar (PSBB), pengurangan kontak sosial, peraturan isolasi mandiri, dan sebagainya.

Pandemi Covid-19 yang bersumber dari gangguan kesehatan ini kemudian berdampak pada berbagai bidang, termasuk sektor ekonomi kemudian sektor keuangan secara global. Semakin cepat dalam mengambil tindakan untuk mengatasi pandemi Covid-19, maka dampak ke sektor ekonomi dan keuangan semakin cepat diminimalisir².

Diprediksi sektor-sektor seperti kegiatankegiatan bisnis, kinerja perdagangan, dan nilai tukar akan mengalami penurunan secara

1Kemkes. Situasi Terkini Perkembangan Coronavirus Disease (COVID-19) 29 April 2020. Diakses dari https://covid19.kemkes.go.id pada tanggal 4 Mei 2020, hal 1.

${ }^{2}$ Bank Indonesia. Perkembangan Terkini Perekonomian dan Langkah BI dalam Hadapi COVID-19 (26 Maret 2020). Diakses dari https://www.bi.go.id/ pada tanggal 20 April 2020, hal 1. drastis 3 . Hasil survei dari Global Consumer Insights tahun 2020 Pricewaterhouse Coopers $(\mathrm{PwC})$ yang bertajuk "Before and After the Covid-19 Outbreak", mengungkapkan bahwa dengan adanya pandemi dan kemudian pemberlakuan PSBB yang diterapkan telah menyebabkan perubahan mendasar. Perubahan mendasar tersebut antara lain: dalam cara konsumen menjaga kesehatannya, bekerja, berkomunikasi, dan makan². Hal ini karena masyarakat harus melakukan kegiatan ibadah, bekerja dan belajar di rumah. Perubahan tersebut tentunya akan berpengaruh terhadap konsumsi masyarakat.

Pandemi Covid-19 tak bisa dipungkiri berdampak pada kondisi ekonomi, yang pada akhirnya mempengaruhi perilaku masyarakat termasuk pola konsumsi masyarakat. Tentunya perubahan pola konsumsi tersebut berpengaruh pula pada tingkat penjualan bisnis terkait. Ada beberapa kategori produk atau jasa yang mengalami peningkatan permintaan secara drastis, sementara di sisi lain sejumlah kategori produk lainnya mengalami penurunan. Meskipun berdampak pada ekonomi, hasil riset menyatakan $40 \%$ konsumen di Indonesia optimis bahwa ekonomi bisa pulih dengan cepat. Namun konsumen tetap berhati-hati dalam pengeluarannya dan banyak yang beralih ke platform online untuk membeli berbagai kebutuhan ${ }^{5}$.

Efendi Haslim Hong, Pengajar Program Studi Manajemen di Fakultas Ekonomi dan

3 Muhamad Choerul A. Rafqie . Pandemik Covid-19 dan Dampaknya Bagi Depresi Ekonomi Indonesia. Diakses dari https://www. Kompasiana.com/ pada tanggal 4 April 2020, hal. 2.

4 Annetly Ngabito. 2020. Survei PwC: Pandemi Mengubah Perilaku Konsumen. Diakses dari https://www.pwc.com/id/ pada tanggal 14 Desember 2020 , hal 1 .

5 Sirclo. 2020. Bagaimana Perubahan Pola Konsumsi Masyarakat Indonesia Selama Pandemi COVID-19? Diakses dari https://www.sirclo.com/ pada tanggal 15 Desember 2020, hal 1. 
Bisnis Unika Atma Jaya, menyatakan bahwa pandemi Covid-19 telah mempengaruhi segala aspek kehidupan manusia. Dampak dari penerapan PSBB sebagian besar orang harus melakukan kegiatan sehari-hari di rumah saja, baik untuk bekerja maupun belajar, termasuk mengubah pola konsumsi masyarakat ${ }^{6}$.

Dalam penelitian Hutauruk, yang berjudul Pengaruh Pandemi Covid-19 terhadap Faktor yang Menentukan Perilaku Konsumen untuk Membeli Barang Kebutuhan Pokok di Samarinda. Mengungkapkankan bahwa terjadinya pandemi Covid-19 kemudian diberlakukannya PSBB oleh pemerintah, memunculkan fenomena baru di dalam hal psikologis dan keputusan konsumen untuk melakukan pembelian terhadap barang kebutuhan pokok, yang sangat jauh berbeda dari sebelum adanya pandemi.

Para penulis dalam Publikasi McKinsey, yakni: Kohli, Timelin, Fabius, dan Veranen memaparkan bahwa adanya pandemi Covid19 di sejumlah negara menyebabkan perubahan perilaku konsumen pada beberapa aspek kehidupan. Hal ini karena dampak adanya lockdown. Saat ini dunia menuju pemulihan dan pembukaan kembali ekonomi. Namun masa penularan, isolasi mandiri, dan ketidakpastian ekonomi akan mengubah cara konsumen berperilaku dalam beberapa kasus selama bertahun-tahun yang akan datang. McKinsey mengemukakan bahwa di tengah perubahan tersebut perusahaan perlu melakukan adaptasi dalam melakukan penjualan, pemasaran, dan lain sebagainya sesuai

6 Gloria F K Lawi. 2020. Begini Pergeseran Perilaku Konsumen Baru selama Pandemi Covid-19. Diakses dari https://ekonomi.bisnis.com/ pada tanggal 14 Desember 2020, hal 1.

7 Martinus Robert Hutauruk. 2020. Pengaruh Pandemi Covid-19 terhadap Faktor yang Menentukan Perilaku Konsumen untuk Membeli Barang Kebutuhan Pokok di Samarinda. Jurnal Riset Inossa Volume 2 Nomor 1 Tahun 2020, hal 13. dengan perubahan perilaku konsumen ${ }^{8}$.

GfK Digital Research melakukan riset untuk menggali lebih dalam perilaku konsumen saat ini dan di masa mendatang, gaya hidup serta mood. Penelitian dilakukan di 30 negara termasuk Indonesia, dilakukan terhadap 500 sampai dengan 1000 konsumen dari setiap negara setiap minggunya. Hasil riset meliputi analisa kebiasaan pengeluaran belanja, konsumsi media dan produk, serta tren mobilitas dan perjalanan konsumen. Hasil riset ini dapat membantu pelaku bisnis untuk dapat mengambil keputusan dan bangkit lebih cepat, serta lebih memastikan dalam berbagai strategi marketing yang tepat. Perusahaanperusahaan dari berbagai sektor industri sebaiknya melakukan penyesuaian bisnisnya mengikuti perubahan kebutuhan konsumen, menyusul penerapan aturan pemerintah dalam mengatasi krisis dampak pandemi Covid-199.

Sejalan dengan pemaparan Sangadji (2013), memahami perilaku dari konsumen sangat penting bagi perusahaan. Tujuan dari memahami perilaku konsumen tersebut adalah untuk memprediksi, menjelaskan dan mengendalikan konsumen. Dengan demikian perusahaan dapat mendesain pola yang tepat untuk mempengaruhi konsumen dan dapat memproduksi barang sesuai dengan selera konsumen ${ }^{10}$.

Pada tahun 2020 penduduk muslim di Indonesia diperkirakan akan mencapai 229,62

8 Sajal Kohli, dkk. 2020. How COVID-19 is Changing Consumer Behavior-Now and Forever. Mc Kinsey \& Company. Diakses dari https://www. mckinsey.com/ pada tanggal 15 Desember 2020, hal1.

${ }^{9}$ GfK Digital Research. 2020. Ini Tren Perilaku Konsumen Pasca Krisis Covid-19. Diakses dari https://www.indotelko.com/ tanggal 14 Desember 2020, hal 1-3.

10 Wiwik Suprihatin. 2020. Analisis Perilaku Konsumen Wisatawan Era Pandemi Covid-19 (Studi Kasus Pariwisata di Nusa Tenggara Barat). Jurnal Bestari Volume 01 Nomor. 01,Agustus 2020, hal 58. 
juta jiwa atau sekira 87,2\%. Mereka akan berperilaku sesuai tuntunan yang diyakininya, salah satunya dalam konsumsi. Hal ini merupakan potensi besar bagi pelaku usaha atau produsen, untuk itu perlu memahami perilaku konsumsi dari sudut pandang perspektif Islam.

Tulisan ini bertujuan untuk mengkaji konsumsi di masa pandemi Covid-19 ditinjau dari Ekonomi Mikro Islam. Untuk itu pendekatan menggunakan kualitatif, metode deskriptif dan analisis eksplorasi dengan studi dokumentasi/teks berupa data-data yang terkait dan studi berbagai literatur. Terdapat dua fokus pembahasan pada artikel ini yakni:

(1) Teori Konsumsi pada Ekonomi Mikro, dan

(2) Konsumsi di masa pandemi Covid-19 ditinjau dari Ekonomi Mikro Islam.

\section{Metode}

Penyusunan artikel dilakukan saat terjadi pandemi Covid-19 di Indonesia, dengan data yang diamati mulai awal pandemi sampai bulan ke sebelas. Menggunakan pendekatan kualitatif, metode diskriptif dan analisis eksplorasi. Dikembangkan dengan menggunakan pendekatan kajian literatur atau studi pustaka yakni berupa buku, jurnal ilmiah dan internet. Penghimpunan data sekunder yang digunakan berasal dari dinas-dinas terkait seperti: Kementerian Kesehatan, Bank Indonesia, dan dari berbagai literatur. Penulis akan mendeskripsikan dan menganalisis dalam artikel serta mengambil kesimpulan dari sumber-sumber data dan kajian literatur tersebut.

\section{PEMBAHASAN}

\section{Teori Konsumsi pada Ekonomi Mikro}

Bertolak dari penelitian Janwari dkk (2020), yang berpendapat bahwa pengertian ilmu Ekonomi Islam tampaknya meng- akomodir pengertian ilmu ekonomi yang dikemukakan oleh para ekonom Barat (konvensional) ${ }^{11}$.

Berikut pengertian ilmu ekonomi yang dikemukakan dua pemikir ekonomi konvensional. Samuelson \& Nordhaus, (1997) pada Colander (2004), ilmu ekonomi adalah satu bidang studi tentang bagaimana manusia melakukan berbagai cara dalam mengorganisasikan kegiatan konsumsi dan produksi. Ini sejalan dengan pengertian dari Eduian Mansfield (1971), yakni mengartikan ekonomi dengan kajian tentang perilaku manusia dalam hubungannya dengan pemanfaatan sumber-sumber produktif yang langka untuk memproduksi barang-barang dan jasa-jasa, kemudian mendistribusikannya untuk dikonsumsi ${ }^{12}$.

Sedangkan Ekonomi Islam menurut Mannan, merupakan suatu studi sosial yang mempelajari masalah ekonomi manusia berdasarkan nilai-nilai Islam $^{13}$. Akram Khan, mengemukakan Ekonomi Islam adalah bagaimana manusia berusaha untuk memperoleh kebahagiaan (falah) dengan cara mendayagunakan sumber-sumber daya yang ada di bumi berdasarkan pada kerja sama dan partisipasi ${ }^{14}$.

Ini artinya bahwa pendekatan-pendekatan dalam teori Ekonomi Konvensional yang selama ini sudah dipelajari dapat digunakan untuk menjelaskan Ekonomi Islam, perbedaannya teori dalam Ekonomi Islam

11 Yadi Janwari dkk. 2020. Ekonomi Islam sebagai Disiplin Ilmu. UIN Sunan Gunung Djati Bandung, hal 4.

12 Yadi Janwari dkk. 2020. Ekonomi Islam sebagai Disiplin Ilmu. UIN Sunan Gunung Djati Bandung, hal 3.

13 Mannan. 1997. Teori dan Praktik Ekonomi Islam. Yogyakarta: PT. Dana Bhakti Prima Yasa, hal19.

14 Muhammad. 2005. Ekonomi Mikro dalam Perspektif Islam. Yogyakarta: BPFE, hal 7. 
dikerangkai nilai-nilai (prinsip) Islam ${ }^{15}$.

Teori-teori dalam Ekonomi Mikro konvensional yang dapat menjelaskan teori konsumsi menurut perspektif Islam, antara lain: keseimbangan pasar (the price of the equivalent), teori konsumsi (perilaku konsumen), serta formula dan persamaan konsumsi. Berikut di bawah ini pemaparannya bertolak dari Lipsey, dkk (1995) dan Iskandar Putong (2013).

\section{Keseimbangan Pasar}

Membicarakan tentang keseimbangan pasar, tentunya akan membicarakan tentang teori permintaan dan penawaran. Ini karena keseimbangan pasar (equilibrium) adalah kondisi bertemunya atau kesamaan antara harga dan jumlah barang yang diminta $\left(Q_{d}\right)$ dengan harga dan jumlah barang yang ditawarkan $\left(Q_{s}\right)^{16}$. Berikut gambar kurva permintaan (D) dan penawaran (S):

\section{Kurva Permintaan}

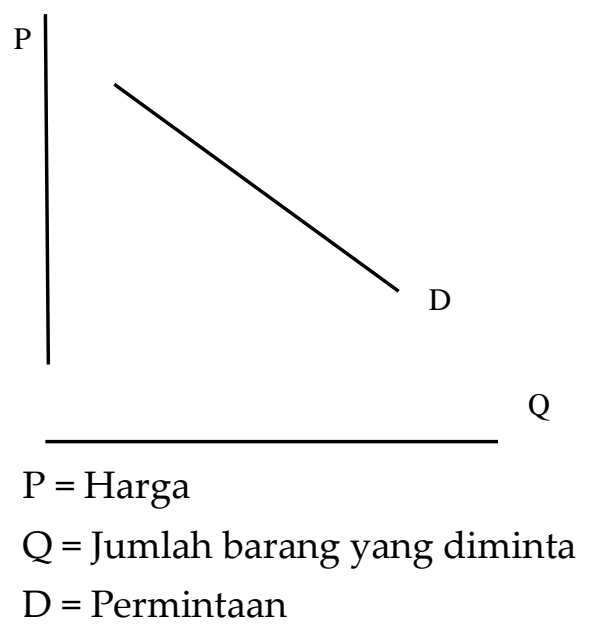

Kurva permintaan tersebut adalah gambaran dari hukum permintaan yang bersifat berbanding terbalik, yakni: "Jika harga suatu

15 Ramadhani Irma. 2008. Perilaku Konsumen Islami. Oiko $\sum$ Jurnal Manajemen Vol 1 No 1 ISSN: 1979-4770, hal 15.

${ }^{16}$ Richard G. Lipsey dkk. 1995. Pengantar Mikro Ekonomi. Jakarta: Binarupa Aksara, hal 94. barang tinggi, maka jumlah barang yang diminta rendah dan sebaliknya. Hukum ini berlaku dengan asumsi cateris paribus". Cateris paribus, artinya bahwa hukum ini berlaku jika yang mempengaruhi hanya faktor (variabel) harga, sedang variabel lain dianggap tetap atau tidak mempengaruhi, misal: pendapatan masyarakat, harga barang subsitusi, harga barang komplementer, selera, dan lain-lain.

Namun jika variabel lainnya selain variabel harga tersebut berubah, maka ini akan menggeser kurva permintaan ke kanan atas atau ke kiri bawah. Berikut gambar pergeseran kurva permintaan dari D ke D 1 .

Pergeseran Kurva Permintaan

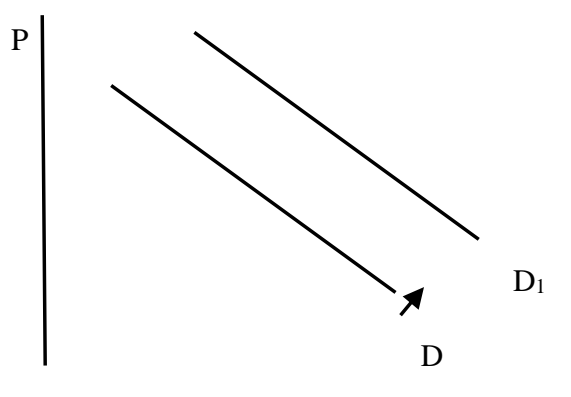

Q

Hukum penawaran yaitu: "Jika harga suatu barang tinggi, maka jumlah barang yang ditawarkan tinggi dan sebaliknya. Hukum ini berlaku dengan asumsi cateris paribus". Jika variabel lain mempengaruhi jumlah barang yang ditawarkan, ini membuat hukum penawaran tidak berlaku, misalnya: harga sumber daya, tujuan perusahaan, teknologi, dan lain-lain. Gambar kurva penawaran:

Kurva Penawaran

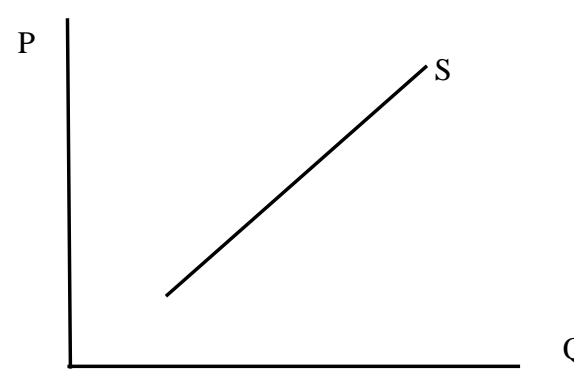

Jurnal Ilmu Akuntansi dan Bisnis Syariah 
$\mathrm{Q}=$ Jumlah barang yang ditawarkan

$\mathrm{S}=$ Penawaran

Begitu pula kurva penawaran tersebut akan bergeser jika variabel lainnya selain variabel harga berubah, maka ini akan menggeser kurva penawaran ke kanan bawah atau ke kiri atas. Berikut gambar pergeseran kurva penawaran dari S ke $S_{1}$.

\section{Pergeseran Kurva Penawaran}

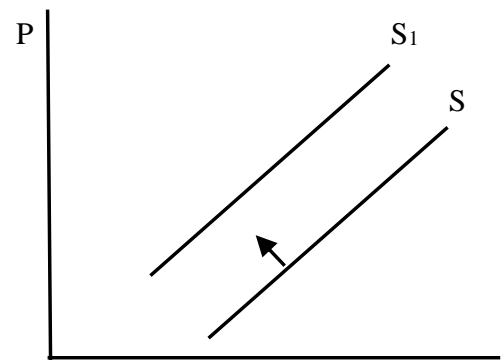

Q

Sifat hukum penawaran atau hubungan antar variabel dalam hukum penawaran adalah sebanding.

Terjadinya pertemuan atau perpotongan antara kurva permintaan dengan kurva penawaran menunjukkan keseimbangan pasar, seperti gambar kurva di bawah ini:

\section{Keseimbangan Pasar}

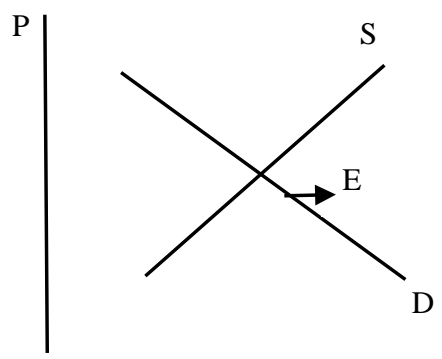

Q

$$
\mathrm{E}=\text { Eqilibrium }
$$

Jika harga di atas harga keseimbangan, maka jumlah yang ditawarkan lebih besar (excess supply) sehingga akan terjadi dimana produsen atau penjual menurunkan harga. Sebaliknya jika harga dibawah harga keseim- bangan, maka jumlah yang diminta lebih besar (excess demand) sehingga produsen akan menaikkan harga. Ini yang disebut mekanisme pasar. Menurut teori ekonomi konvesional mekanisme pasar tersebut cenderung akan terbentuk secara otomatis, hanya sedikit campur tangan pemerintah.

\section{Teori Konsumsi}

Konsep dasar teori konsumsi konvensional adalah menjelaskan bagaimana konsumen mendayagunakan sumber dayanya (uang) dalam rangka memuaskan kebutuhan (keinginan) dari suatu atau beberapa produk yang dikonsumsi. Terdapat dua pendekatan dalam teori ini: (1) Nilai Guna Kardinal (Cardinal Utility); dan (2) Nilai Guna Ordinal (Ordinal Utility).

\section{Cardinal Utility}

Teori Cardinal Utility memberikan penilaian subyektif akan pemuasan kebutuhan dari suatu barang atau jasa. Tinggi rendahnya suatu barang tergantung pada subyek yang memberikan penilaian. Pelopor teori ini adalah Gossen, Walras, Jevons. Teori ini berupaya untuk mengkuantifikasi kepuasan (utility). Asumsi-asumsi yang digunakan teori ini, yaitu : (a) Daya guna diukur dalam satuan uang, dimana konsumen bersedia membayar dalam rangka menambah unit yang akan dikonsumsi. (b) Daya guna marginal dari uang tetap, yakni nilai suatu uang dalam satuannya adalah sama untuk setiap orang tanpa memandang statusnya. (c) Additivitas merupakan total utility, yakni keseluruhan konsumsi dari barang. (d) Periode konsumsi berdekatan dan dengan jumlah yang sama.

Pada dasarnya teori ini menggunakan pengalaman sehari-hari dalam kegiatan konsumsinya, misal saat seseorang mengkonsumsi air minum. Pada satu gelas pertama, 
nilai air tersebut sangat tinggi tapi pada gelas berikutnya nilai air tersebut berkurang. Teori ini cenderung menjelaskan konsumsi dalam jangka pendek.

Jenis Nilai Guna (Kepuasan), meliputi : (a) Total Utility (TU atau Total Kepuasan), yaitu keseluruhan nilai guna yang diperoleh seseorang sebagai akibat mengkonsumsi suatu barang, misal barang x; dan (b) Marginal Utility (MU atau Tambahan Kepuasan), yaitu tambahan kepuasan yang diperoleh seseorang akibat dari menambah satu unit barang yang dikonsumsi untuk memenuhi kepuasannya. Formulanya adalah $\mathrm{MU}=\Delta \mathrm{TU}: \Delta \mathrm{x}$.

Di bawah ini adalah simulasi jika seseorang mengkosumsi barang $x$ dalam berbagai unit: mulai dari 0, 1, 2, 3 dan seterusnya. Ditunjukkan oleh tabel dan gambar Cardinal Utility berikut:

Total Utility dan Marginal Utility dari mengkonsumsi Unit Barang $\mathrm{x}$

\begin{tabular}{|c|c|c|}
\hline $\begin{array}{r}\text { Konsumsi } \\
\text { (x) dalam unit }\end{array}$ & $\begin{array}{r}\text { Total } \\
\text { Utility (TU) }\end{array}$ & $\begin{array}{r}\text { Marginal } \\
\text { Utility (MU) }\end{array}$ \\
\hline 0 & 0 & - \\
1 & 9 & 9 \\
2 & 16 & 7 \\
3 & 21 & 5 \\
4 & 24 & 3 \\
5 & 25 & 1 \\
6 & 24 & -1 \\
7 & 21 & -3 \\
\hline
\end{tabular}

Kemudian dari tabel tersebut dibuatkan grafik (kurvanya) sebagai berikut:
Total Utility dan Marginal Utility dari mengkonsumsi Unit Barang $x$

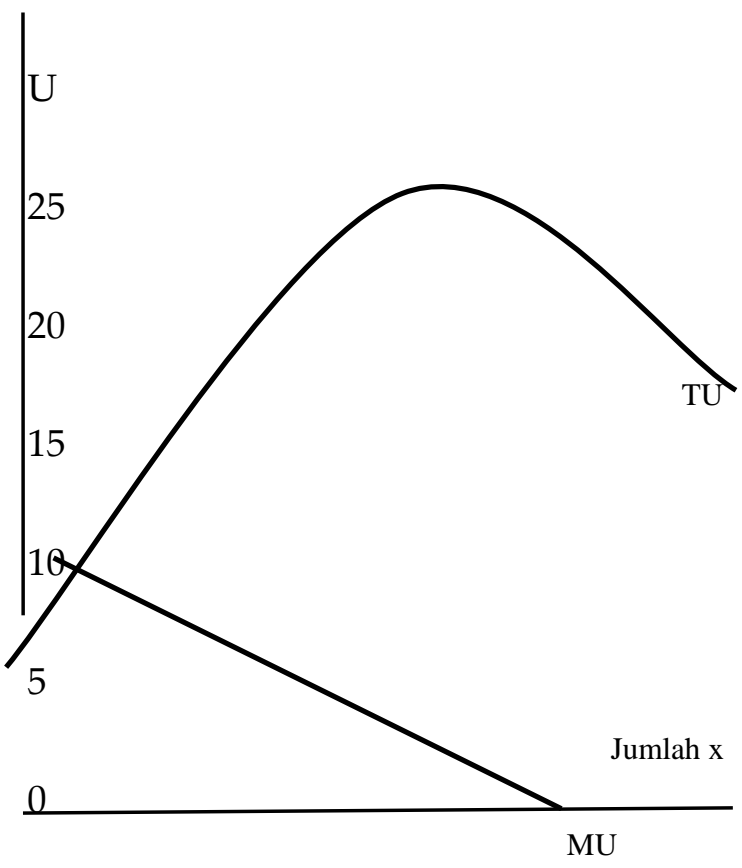

Grafik di atas menggambarkan berlakunya Hukum Gossen I dalam teori ini, bunyi hukum ini yakni "Semakin banyak barang dikonsumsi maka total kepuasan (TU) setelah mencapai maksimum makin lama makin menurun, sedangkan tambahan kepuasan (MU) makin menurun" atau dikenal dengan "The law of diminishing marginal utility".

\section{Ordinal Utility}

Teori Ordinal Utility bersifat objektif. Artinya tinggi rendahnya nilai guna (kepuasan) tergantung pada objek atau barang/jasa yang dikonsumsi. Dalam teori ini tingkat kepuasan diurutkan dalam tingkat kepuasan tertentu, yakni: rendah, sedang dan tinggi. Tokoh yang mempelopori teori ini adalah Hikcks dan Allen. Untuk menjelaskan teori Ordinal Utility digunakan Indifference Curve, yaitu kurva yang menggambarkan kombinasi dua barang yang dikonsumsi untuk menghasilkan tingkat kepuasan yang sama.

Asumsi-asumsi yang digunakan teori ini : (a) Rasionalitas, yakni konsumen akan berusaha meningkatkan kepuasannya atau akan 
memilih tingkat kepuasan tertinggi yang bisa dicapainya. (b) Konveksitas, yakni bentuk Indifference Curve yang cekung dari titik origin sumbu absis dan ordinat. (c) Nilai guna tergantung barang yang dikonsumsi. (d) Transitivitas, yakni konsumen akan menjatuhkan pilihan yang terbaik. (e) Berdasarkan asumsi ke 4, antara Indifference Curve tidak boleh saling berpotongan.

Berikut adalah tabel dan gambar Indifference Curve:

Kombinasi dari Mengkonsumsi Barang x dan $\mathrm{y}$

\begin{tabular}{|c|c|c|}
\hline $\begin{array}{c}\text { Kombinasi } \\
\text { Konsumsi }\end{array}$ & $\begin{array}{c}\text { Jumlah } \\
\text { Barang } \mathbf{x}\end{array}$ & $\begin{array}{c}\text { Jumlah } \\
\text { Barang } \mathbf{y}\end{array}$ \\
\hline A & 1 & 3 \\
B & 3 & 1 \\
C & 2 & 7 \\
D & 4 & 5 \\
\hline
\end{tabular}

Gambar dari tabel di atas, sebagai berikut:

Indifference Curve dan Tingkat Kepuasan (Nilai Guna) dari Mengkonsumsi Barang x dan y

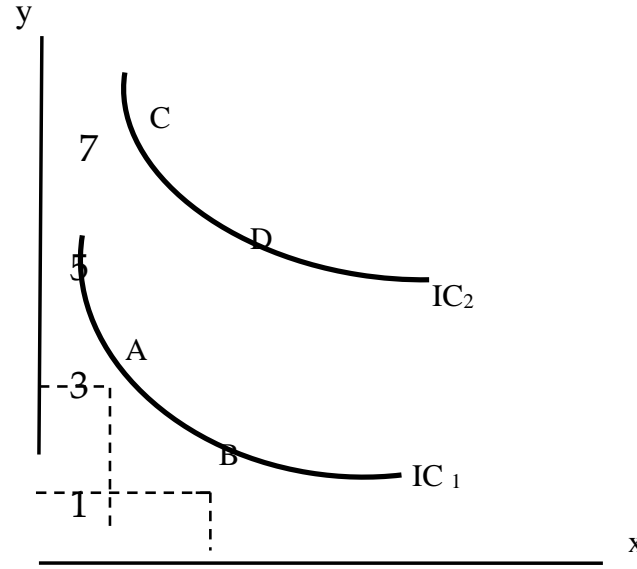

$\begin{array}{llll}1 & 3 & 5 & 7\end{array}$

Kombinasi konsumsi barang pada titik A ( 1 unit barang $x$ dan 3 unit barang $y$ ) dan titik B ( 3 unit barang $x$ dan 1 unit barang $y$ ) menunjukkan tingkat kepuasan yang sama karena terletak pada satu kurva. Kurva semakin ke kanan atas ( $\mathrm{IC}_{1}$ bergeser $\left.\mathrm{IC}_{2}\right)$ menunjukkan tingkat kepuasan semakin tinggi, artinya kombinasi konsumsi pada titik $\mathrm{C}$ dan D menghasilkan tingkat kepuasan lebih tinggi daripada titik A dan B.

Syarat kepuasan maksimum terhadap barang yang dikonsumsi, terjadi jika Marginal Utility barang $x$ dibanding dengan harganya sama dengan Marginal Utility barang y dibanding dengan harganya. Notasi secara matematis adalah :

$$
\frac{\mathrm{MU}_{(\mathrm{X})}}{\mathrm{P}_{(\mathrm{x})}}=\frac{\mathrm{MU}_{(\mathrm{Y})}}{\mathrm{P}_{(\mathrm{Y})}}=1
$$

$$
\begin{aligned}
& \mathrm{MU}=\text { Marginal Utility } \\
& \mathrm{P} \quad=\text { Harga }
\end{aligned}
$$

Keinginan untuk mencapai kepuasan tentu ada batasnya, yakni dibatasi oleh sumber daya (anggaran) yang dimiliki. Inilah yang disebut Budget Constraint (keterbatasan anggaran). Adanya Budget Constraint tersebut maka tingkat kepuasan maksimum dibatasi oleh anggaran (uang), ditunjukkan oleh gambar berikut :

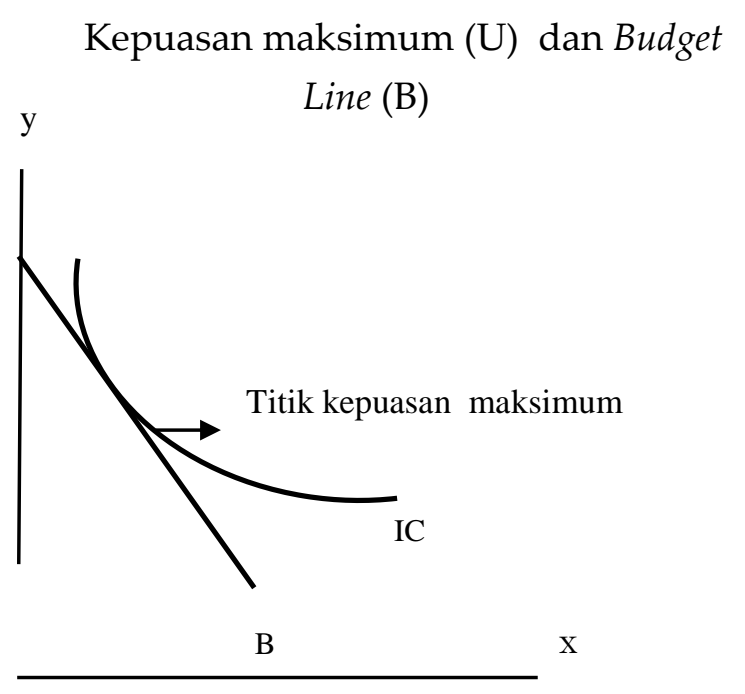

Kepuasan maksimum konsumen dapat dicapai bila: (1) Indifference Curve tertinggi 
yang bersinggungan dengan Budget Line; (2)

Terjadi pada titik singgung antara Indifference Curve tertinggi dengan Budget Line (garis anggaran).

\section{Formula Konsumsi}

Terkait dengan teori konsumsi, formula konsumsi menurut teori perekonomian dimana asumsinya hanya terdapat dua pelaku ekonomi yakni sektor rumah tangga konsumen dan sektor rumah tangga produsen, atau istilahnya perekonomian tertutup sederhana ditunjukkan oleh :

$$
\mathrm{Y}=\mathrm{C}+\mathrm{S}
$$

$$
\begin{aligned}
& \mathrm{Y}=\text { pendapatan } \mathrm{C}=\text { konsumsi } \\
& \mathrm{S}=\text { tabungan }
\end{aligned}
$$

Formulasi di atas menggambarkan bahwa pendapatan seseorang digunakan untuk konsumsi dan menabung. Kemampuan masyarakat untuk menabung adalah sebesar sisa pendapatannya setelah untuk konsumsi. Formula tersebut menunjukkan bahwa besarnya konsumsi dipengaruhi oleh besarnya pendapatan, dinotasikan dalam fungsi konsumsi sebagai berikut:

$$
\mathrm{C}=\mathrm{f}(\mathrm{Y})
$$

Dari fungsi konsumsi, kemudian dijabarkan dalam bentuk persamaan konsumsi:

$$
\mathrm{C}=\mathrm{a}+\mathrm{bY}
$$

$\mathrm{a}=$ besarnya konsumsi jika pendapatan sama dengan 0 .

$\mathrm{b}=$ besarnya perubahan konsumsi akibat perubahan pendapatan.

\section{Konsumsi di Masa Pandemi Covid-19 Ditinjau dari Ekonomi Mikro Islam}

Hasil survei Global Consumer Insights 2020 PwC mengungkapkan, pandemi Covid19 dan penerapan PSBB menyebabkan perubahan mendasar salah satunya konsumsi. Survey dilakukan disejumlah negara termasuk Indonesia. Survei pertama terkumpul jawaban dari 19.098 konsumen dari 27 negara atau wilayah dan 74 kota, antara bulan Agustus dan September 2019. Survei kedua terkumpul jawaban dari 4.447 konsumen dari 9 negara atau wilayah dan 35 kota antara bulan April dan Mei 2020.

Dalam hal pengeluaran untuk konsumsi di Indonesia, lima besar peningkatan belanja konsumen Indonesia adalah $77 \%$ produk kesehatan, $67 \%$ bahan makanan, 54\% hiburan dan media, $47 \%$ pengiriman makanan serta $32 \%$ perbaikan rumah dan berkebun. Sebesar 65\% konsumen Indonesia mengalami penurunan pendapatan rumah tangga.

Lebih dari sepertiga konsumen (35\%) sekarang membeli makanan secara online, di mana $86 \%$ dari konsumen tersebut berencana untuk terus melakukannya bahkan setelah PSBB dihapuskan. Sementara belanja online untuk barang-barang selain makanan mengalami peningkatan yang substansial, melalui perangkat ponsel sebesar $45 \%$; komputer $41 \%$; dan tablet $33 \%$.

Hasil riset GfK Digital Research, menyediakan informasi bagi para pelaku bisnis dengan berbagai kategori. Hasil riset bermanfaat untuk mengeksplorasi peluang-peluang yang bisa memberikan dampak positif terhadap pertumbuhan bisnis di masa mendatang, serta mendukung pemulihan bisnis mereka secara efektif selama dan pasca krisis.

Hasil riset tersebut antara lain, sebesar $47 \%$ responden yang menyatakan bahwa 
kondisi keuangan mereka telah mengalami penurunan dibandingkan tahun lalu. Sehubungan dengan adanya PSBB, waktu yang dihabiskan masyarakat untuk aktivitas di luar rumah berkurang $80 \%$. Bahkan, di antara responden yang memiliki kemungkinan kegiatan dari rumah, 50\% diantaranya menjalankan aktivitas work from home (WFH) secara full time. Dan sebanyak 55\% pelajar melakukan kegiatan belajar di rumah (SFH).

Sebanyak 50\% masyarakat Indonesia masih memilih untuk berbelanja langsung di toko dibandingkan belanja online. Sebesar $14 \%$ responden yang menyatakan lebih memilih untuk eksklusif berbelanja online. Hasil riset tersebut menunjukkan, bahwa responden melaksanakan belanja online lebih sering dari biasanya guna membeli kebutuhan sehari-hari seperti: makanan, produk kebersihan, dan perawatan pribadi. Peningkatan permintaan juga terjadi pada kategori produk lainnya seperti hiburan, kecantikan, dan produk keuangan. Sementara, Sebesar $55 \%$ responden Indonesia menghadapi harga yang lebih tinggi untuk beberapa produk keperluan sehari-hari.

Di sisi lain sebagian besar masyarakat Indonesia memilih untuk menunda pembelian beberapa barang, seperti: smartphone, peralatan rumah tangga, komputer, elektronik, perawatan mobil, dan jasa renovasi rumah.

Penjualan ritel dari barang-barang elektronik sangat terdampak oleh situasi ini, yakni mengalami lebih dari $60 \%$ penurunan dari nilai penjualan pada awal April 2020 dibandingkan tahun lalu. Produk tersebut yang paling terdampak diantaranya adalah smartphone, tablet, dan televisi.

Laporan hasil riset dari McKinsey, mengemukakan bahwa pandemi Covid-19 berdampak pada kondisi ekonomi masya- rakat. Konsumen menjadi lebih berhati-hati dalam membelanjaka uangnya sebesar $83 \%$ dan $65 \%$ konsumen mengurangi pengeluaran.

Rata-rata konsumen mengurangi pengeluaran dalam seluruh kategori produk, kecuali kebutuhan rumah tangga seperti bahan makanan, perlengkapan rumah tangga, produk perawatan pribadi, dan hiburan dalam rumah. Di samping itu masyarakat juga mulai memiliki kebiasaan baru lewat aktivitas digital, seperti:, belanja bahan baku, pemesanan makanan dari restoran, pengiriman online, dan online streaming.

Meskipun sejumlah aktivitas di luar rumah mulai berangsur-angsur kembali seperti biasa di era kebiasaan baru (new normal), masyarakat tetap berencana untuk tetap melanjutkan berbelanja online untuk sebagian besar kategori produk. Sementara aktivitas belanja langsung di toko masih cenderung menurun. Beberapa kategori produk yang dibeli secara online mengalami pertumbuhan yang cukup signifikan dibanding sebelum adanya pandemi antara lain: vitamin dan obat-obatan, makanan kecil (snack), peralatan rumah tangga, produk anak-anak, buku dan majalah.

Selanjutnya McKinsey menyebutkan sekitar 92\% konsumen telah mencoba metode berbelanja baru selama pandemi. Sebesar $58 \%$ konsumen berbelanja secara digital, $48 \%$ berbelanja melalui layanan pick-up dan aplikasi pengiriman, dan $37 \%$ mencoba brand baru.

Bertolak dari data di atas, akan dibahas konsumsi di masa pandemi Covid-19 ditinjau dari Ekonomi Mikro Islam dengan pendekatan-pendekatan teori ekonomi konvensional. Ekonomi Mikro Islam, adalah bagaimana variabel-variabel ekonomi mikro tidak hanya dijadikan alat analisis atau landasan 
keputusan oleh unit ekonomi saja, namun juga memasukkan prinsip-prinsip dan batasbatas syariah sebagai landasannya.

Samuelson (1999), mengemukakan salah satu tujuan ekonomi adalah untuk menjelaskan dasar-dasar perilaku konsumen ${ }^{17}$. Pendalaman tentang hukum permintaan dan mengetahui bahwa orang akan cenderung membeli lebih banyak barang jika harga barang itu rendah, begitu pula sebaliknya. Selanjutnya dasar pemikirannya tentang perilaku konsumen, bahwa orang cenderung memutuskan memilih barang dan jasa yang nilai kegunaannya (utility) paling tinggi. Di samping itu konsumen akan memilih barang kebutuhan pokok untuk dikonsumsi, dengan mempertimbangkan nilai guna dari barang tersebut atau disebut pendekatan indifference curve. Keterbatasan anggaran (budget) pada masyarakat, menyebabkan masyarakat harus menunda untuk mengkonsumsi barang-barang yang memiliki nilai guna tinggi.

Produk-produk yang mengalami peningkatan permintaan dari hasil riset, antara lain: produk kesehatan atau produk perawatan pribadi, bahan makanan, perlengkapan rumah tangga, hiburan dan media on line, pemesanan secara digital dan pengiriman makanan atau produk pokok lainnya, berkebun, buku, serta majalah. Di sini hukum permintaan tidak berlaku karena yang mempengaruhi perubahan bukanlah variabel harga, namun variabel lain yakni adanya suatu kejadian tertentu.

Ini sejalan dengan pandangan $\mathrm{Abu}$ Yusuf (731-789 M) salah satu pemikir Ekonomi Islam. Hasil penelitiannya mengatakan bahwa, kadang makanan berlimpah tetapi

17 Sri Wahyuni. 2013. Teori Konsumsi dan Produksi dalam Perspektif Ekonomi Islam. Jurnal Akuntabel. Volume 10 No. 1 Maret 2013, hal 75. tetap mahal dan kadang makanan sangat sedikit tetapi murah. Tidak ada batas tertentu murah dan mahalnya harga barang yang dapat dipastikan. Murahnya harga tidak disebabkan oleh banyaknya makanan, dan mahalnya harga bukan disebabkan oleh kelangkaan. Kadang makanan sangat sedikit tetapi murah. Hal tersebut ada yang mengatur-Nya. Kesemuanya tunduk pada perintah dan keputusan Allah. Abu Yusuf menegaskan ada beberapa variabel lain yang mempengaruhi, tetapi tidak bisa menjelaskan lebih rinci ${ }^{18}$.

Karena ada variabel lain yang mempengaruhi, maka terjadi pergeseran permintaan, jika digambarkan kurvanya sebagai berikut:

Pergeseran Kurva Permintaan di Masa Pandemi Covid-19

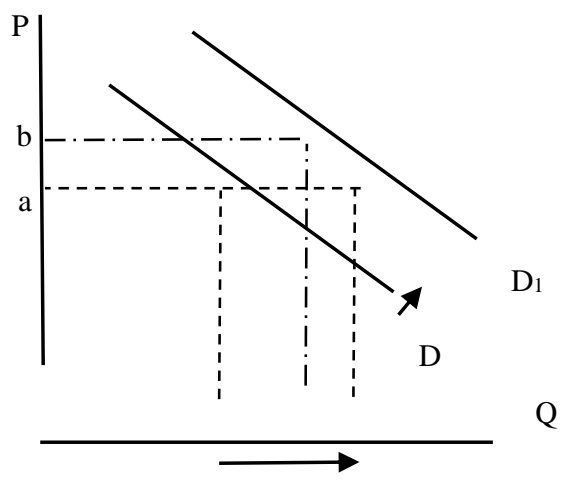

Kurva permintaan tersebut bergeser ke kanan atas $\left(\mathrm{D} \rightarrow \mathrm{D}_{1}\right)$. Gambar di atas juga memperlihatkan kuantitas barang yang diminta mengalami peningkatan, ditunjukkan bergerak ke kanan. Harga bisa dalam keadaan tetap (titik a), atau bisa naik (titik b) tergantung persedian barang yang ditawarkan.

Pergeseran tersebut sejalan dengan pandangan Ibn Khaldun (1332-1404 M) dalam hal naiknya permintaan terhadap barang mewah karena kenaikan disposible income (pendapatan siap digunakan untuk kon-

18 Muhammad. 2005. Ekonomi Mikro dalam Perspektif Islam. Yogyakarta: BPFE, hal 352. 
sumsi) seiring dengan berkembangnya kota. Sehingga kemudian terjadi pergeseran kurva permintaan dari D ke $\mathrm{D}_{1}{ }^{19}$. Pemikiran $\mathrm{Ibn}$ Khaldun melengkapi pernyataan dari Abu Yusuf bahwa ada beberapa variabel lain yang mempengaruhi, sehingga hukum permintaan sifatnya tidak berbanding terbalik. Dalam ekonomi konvensional dikatakan bahwa cateris paribus tidak berlaku sehingga hukum permintaan tidak berlaku pada kasus ini, karena ada variabel lain selain harga yang mempengaruhi. Variabel lain tersebut dalam penelitian Ibn Khaldun adalah kenaikan pendapatan.

Produk-produk yang mengalami penurunan permintaan di masa pandemi Covid 19, antara lain: smartphone, komputer, elektronik, perawatan mobil, dan jasa renovasi rumah. Digambarkan pergeseran permintaannya sebagai berikut:

Pergeseran Kurva Permintaan di Masa Pandemi Covid 19

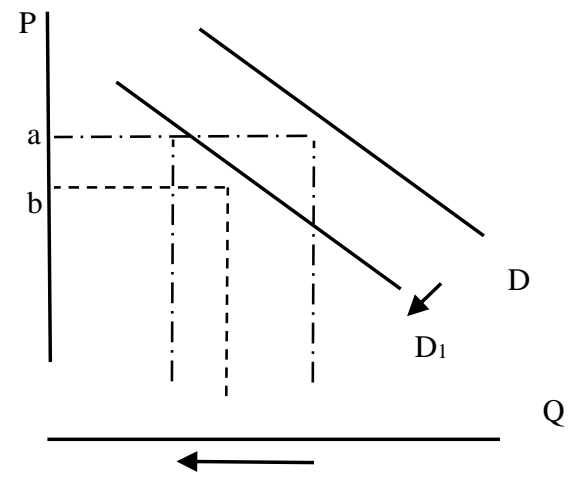

Sebaliknya dengan perseran permintaan sebelumnya. Kurva permintaan tersebut bergeser ke kiri bawah $\left(D \rightarrow D_{1}\right)$. Kuantitas barang yang diminta mengalami penurunan, ditunjukkan bergerak ke kiri. Harga bisa dalam keadaan tetap (titik a), atau bisa turun (titik b) tergantung persedian barang yang ditawarkan.

Begitu pula kurva penawaran akan ber-

19 Muhammad. 2005. Ekonomi Mikro dalam Perspektif Islam. Yogyakarta: BPFE, hal 361. geser jika variabel lainnya selain variabel harga berubah, maka ini akan menggeser kurva penawaran ke kanan bawah atau ke kiri atas. Berikut gambar pergeseran kurva penawaran dari $S$ ke $S_{1}$.

\section{Pergeseran Kurva Penawaran di Masa Pandemi Covid 19}

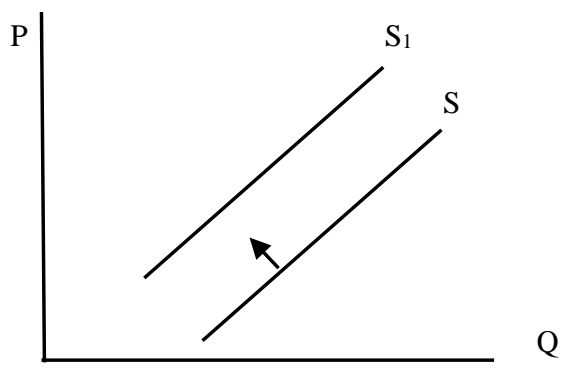

Ibn Taimiyah (1283-1328 M) mengemukakan hasil pemikirannya dengan pendekatan seperti di atas. Kenaikan harga produksi yang ditanggung perusahaan menyebabkan kurva penawaran bergeser dari $S$ ke $S_{1}$ dan penurunan kuantitas barang yang ditawar$\mathrm{kan}^{20}$. Pada peristiwa pandemi sekarang contoh pergeseran penawaran salah satunya adalah kelangkaan masker kesehatan serta harganya naik di awal-awal pandemi.

Terjadinya pertemuan atau perpotongan antara kurva permintaan dengan kurva penawaran menunjukkan keseimbangan pasar, berikut gambar kurvanya:

Keseimbangan Pasar di Masa Pandemi Covid 19

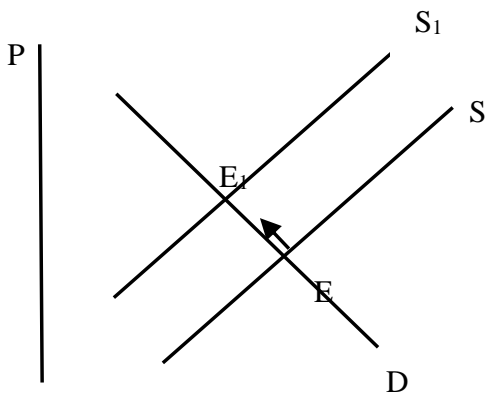

Q

20 Muhammad. 2005. Ekonomi Mikro dalam Perspektif Islam. Yogyakarta: BPFE, hal 357. 
Keseimbangan pasar terjadi pada titik E, yakni perpotongan kurva permintaan dan penawaran dalam keadaan rela sama rela (antaraddim minkum), sebagaimana dalam $\mathrm{Al}$ Qur'an Annisa (QS 4:29). Penjual dan pembeli tidak ada yang terpaksa atau tertipu atau ada kekeliruan dalam objek transaksi. Islam menjamin pasar bebas, di mana para penjual dan para pembeli dapat bertransaksi dengan arus informasi yang berjalan lancar dalam kerangka keadilan, yakni tidak ada yang dzalim atau didzalimi. Pergeseran permintaan atau penawaran atau keduanya, menyebabkan keseimbangan pasar juga turut bergeser. Salah satu contoh seperti gambar di atas, yakni keseimbangan pasar bergeser dari E ke E1.

Kondisi keseimbangan pasar karena pengaruh situasi tertentu kadang tidak tercapai, hal ini karena adanya gangguan atau interupsi pada mekanisme pasar tersebut. Gangguan ini dikenal sebagai distorsi pasar (market distortion). Terdapat beberapa bentuk distorsi pasar, antara lain: ba'i najasy (permintaan palsu), ihtikar (penimbunan), tadlis (penipuan) dan taghrir (ketidakpastian) ${ }^{21}$. Bila ada yang mengganggu keseimbangan pasar bukan karena distorsi pasar, pemerintah harus melakukan intervensi pasar. Namun jika penyebabnya distorsi pasar maka yang dilakukan adalah menghilangkan distorsi tersebut. Dengan demikian melalui tindakan-tindakan tersebut keseimbangan pasar tercapai kembali, harga terjangkau bagi pembeli dan penjual masih menerima margin sebagai keuntungan.

Perbedaan Ekonomi Konvensional dengan Ekonomi Islam dalam hal konsumsi terletak pada cara pendekatannya dalam

21 Adiwarman Karim. 2010. Ekonomi Mikro Islami. Jakarta: PT. Raja Grafindo Persada, hal 181. memenuhi kebutuhan. Pola konsumsi konvensional cenderung berdasarkan pada pola materialistis. Tingkat keberhasilan masyarakat akan diukur dengan keberhasilan mereka dalam menguasi materi. Etika ekonomi Islam berusaha mengalihkan potensi sumber dayanya untuk mengejar kebutuhan materialistik kepada kebutuhan yang sebenarnya.

Pandangan Mannan, konsumsi Islami merupakan konsumsi yang berpedoman pada ajaran Islam. Salah satunya menggunakan konsep maslahah, karena sesuai dengan rasionalitas Islam. Rasionalitas tersebut yakni bahwa setiap pelaku ekonomi selalu ingin meningkatkan maslahah yang didapatkan. Di dalam maslahah tersebut terdiri dari unsur manfaat dan berkah. Serta mengandung unsur spiritual yakni halal dan haram $^{22}$.

Sumber kaidah (dalil) konsumsi dalam Islam adalah Al Qur'an dan As Sunnah. Sehingga dapat dikatakan orang Islam akan mencapai tingkat ekonomi yang baik atau mencapai kepuasan maksimal dalam konsumsi apabila konsumsi tersebut dilakukan sesuai dengan ajaran agama.

Prinsip konsumsi dalam Islam mengutip pandangan Mannan, meliputi: (1) keadilan, agar tidak membahayakan tubuh baik fisik maupun spiritual sesuai firman Allah SWT dalam Q.S. Al Baqarah (2:173); (2) kebersihan, prinsip ini mengatur bahwa makanan yang dikonsumsi haruslah cocok untuk dimakan (thoyib), tidak menjijikkan sehingga merusak selera dan tubuh, sesuai dengan hadits: "Makanan yang diberkahi jika kita mencuci tangan sebelum dan setelah memakannya" (Tarmidzi, Mishkat); kesederhanaan, sebaiknya barang dan jasa

22 Fadhel Ihsan, dkk. 2015. Stdi Analisis Pemikiran Muhammad Abdul Mannan tentang Konsep Konsumsi dalam Ekonomi Islam. Prosiding Penelitian SPeSIA 2015, hal 21. 
yang dikosumsi tidaklah berlebih-lebihan, sebagaimana tercantum dalam $\mathrm{Al}$ A'raf (7:31); (4) kemurahan hati, dengan mentaati perintah Islam yaitu makan dan minum yang halal maka tiada bahaya maupun dosa, inilah kemurahan hati Allah. Namun Allah membolehkan makanan-minuman terlarang dalam keadaan darurat, sebagaimana dalam Al Maidah (5:96); (5) moralitas, prinsip ini mengajarkan bahwa sebelum dan setelah makan mengucapkan rasa syukur kepadaNya. Ini menandakan bahwa kita merasakan selalu kehadiran-Nya.

Menurut Islam tujuan konsumsi adalah untuk memperoleh maslahah (meraih manfaat) terbesar, sehingga manusia dapat mencapai kemenangan di dunia dan akhirat. Jika ditinjau dari konsep efisiensi, dalam ekonomi konvensional adalah memaksimumkan kepuasan (utility) keinginan dengan sumbersumber yang memadai. Efisiensi dalam kerangka Islam adalah memaksimumkan pemenuhan kebutuhan dengan sumbersumber yang memadai. Maslahah terkait dengan kebutuhan (need), sedangkan utility terkait dengan keinginan (want). Dalam tataran perilaku konsumen, maslahah diartikan sebagai konsep pemetaan perilaku konsumen berdasarkan asas kebutuhan dan prioritas.

Konsumsi Islam tidak menganjurkan pemenuhan keinginan yang tak terbatas, norma Islam adalah memenuhi kebutuhan manusia. Dalam memenuhi kebutuhan tersebut Islam menyarankan manusia untuk bertindak ditengah-tengah (moderity) dan sederhana (simplicity). Batasan dalam konsumsi diantaranya tidak melakukan ishraf (berlebih-lebihan) dan tabdzir/ mubazir (pemborosan). Manusia harus mampu membedakan mana yang menjadi kebutuhan dan keinginannya, harus bisa mengedepankan kemaslahahan diri, keluarga dan sosial. Ini dilandasi surah Al A'raf (7:31): “...makan dan minumlah, tetapi jangan berlebih-lebihan; sesungguhnya Allah tidak menyukai orang yang berlebih-lebihan". Terkait batasan konsumsi tersebut, dalam konsep Islam mengenal adanya pembatasan konsumsi yang termasuk halal dan haram ${ }^{23}$.

Beberapa dalil lainnya dari Al Qur'an terkait konsumsi di atas, antara lain:

1. “Hai sekalian manusia, makanlah yang halal lagi baik dari apa yang terdapat di bumi..." (Al Baqarah (2):168).

2. "Sesungguhnya pemboros-pemboros itu adalah saudara-saudara syaitan dan syaitan itu adalah sangat ingkar kepada Tuhannya.." (Al Isra' (17):27).

3. "Makanlah di antara rezeki yang baik yang telah Kami berikan kepadamu, dan janganlah melampaui batas padanya, yang menyebabkan kemurkaan-Ku menimpamu..." (Thaha (20):81).

4. “Dan orang-orang yang apabila membelanjakan (harta), mereka tidak berlebihlebihan, dan tidak (pula) kikir, dan adalah (pembelanjaan itu) di tengahtengah antara yang demikian." (Al Furqon (25):67).

5. “Makanlah, minumlah, berpakaianlah dan bersedekahlah tanpa kecongkakan dan berlebih-lebihan, karena sesungguhnya Allah suka melihat nikmat-Nya atas hamba-Nya." (H.R. Ahmad).

Kepuasan konsumen menurut kerangka Islam tersebut, dapat dijelaskan dengan pendekatan Cardinal Utility sebagai berikut :

23 Sri Wahyuni. 2013. Teori Konsumsi dan Produksi dalam Perspektif Ekonomi Islam. Jurnal Akuntabel. Volume 10 No. 1 Maret 2013, hal 75. 
Batas-batas Kepuasan (Maslahah) dalam Konsumsi Islami

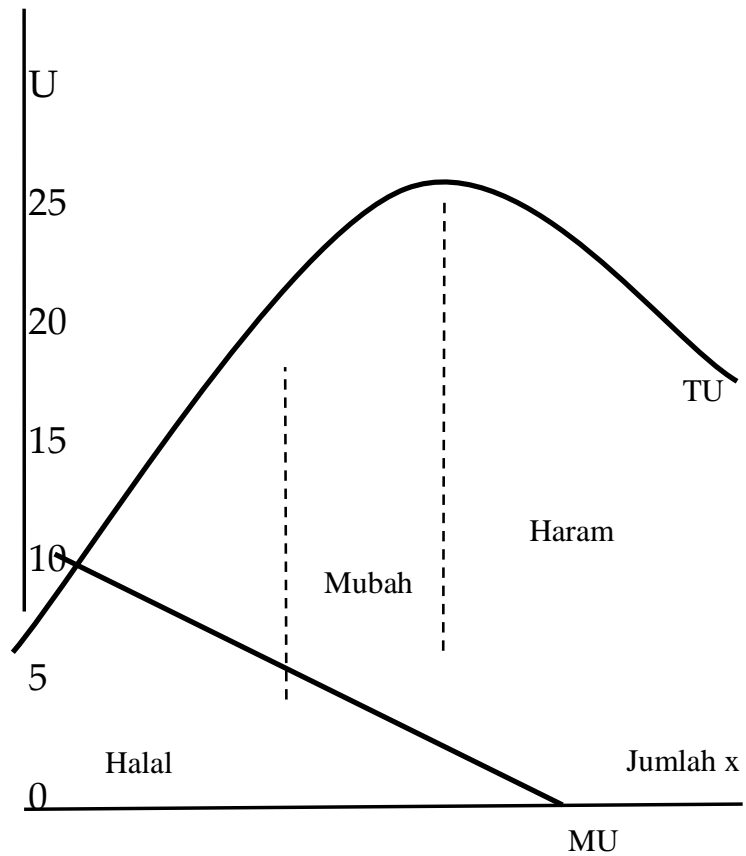

Menurut teori Cardinal Utility berlaku Hukum Gossen I. Dalam Islam ada tiga hukum yang berlaku dalam konsumsi, yaitu : halal, mubah dan haram, yang melandasi batas-batas kepuasan (maslahah) dalam konsumsi Islami. (1) Area halal, yaitu area dimana seseorang boleh dan dianjurkan konsumsi; (2) Area mubah, yaitu area dimana seseorang harus berhati-hati dalam konsumsi, karena telah mencapai kepuasan maksimum; (3) Area haram, yaitu area dimana seseorang telah mencapai kepuasan maksimum tapi ingin menambah konsumsinya.

Dilandasi oleh dari dalil-dalil di atas, maka perilaku konsumen muslim - dijelaskan dengan pendekatan Cardinal Utilitysebaiknya membuat batasan-batasan saat kapan tingkat kepuasan konsumsinya memasuki hukum halal, mubah atau haram. Sehingga seseorang muslim dapat mengetahui rambu-rambu terhadap konsumsinya agar sesuai dengan prinsip Islam, semisal konsumsi suatu barang bisa bergeser menjadi haram hukumnya karena perilaku konsumsinya yang berlebihan.

Tingkat kepuasan menurut pendekatan teori Ordinal Utility digambarkan oleh Indifference Curve, yaitu kurva menggambarkan tingkat kepuasan antara dua barang yang dikonsumsi. Perilaku konsumen menurut Islam dapat dijelaskan dengan pendekatan ini, yaitu mengenai perilaku konsumen terhadap barang halal seperti yang dianjurkan dalam Al Quran, diantaranya : "Hai sekalian manusia, makanlah yang halal lagi baik dari apa yang terdapat di bumi, dan janganlah kamu mengikuti langkahlangkah syaitan; karena sesungguhnya syaitan itu adalah musuh yang nyata bagimu." (Al Baqarah (2):168).

Dalam Islam sangatlah penting adanya pembatasan konsumsi barang atau jasa antara yang haram dan halal. Manusia dilarang untuk menghalalkan apa yang ditetapkan haram dan mengharamkan apa-apa yang sudah halal, sebagaimana Surah Al Maidah (QS 5:87-88) yang artinya :"Hai orang-orang yang beriman, janganlah kamu mengharamkan apa-apa yang baik yang telah Allah halalkan bagi kamu, dan janganlah kamu melampaui batas. Sesungguhnya Allah tidak menyukai orang-orang yang melampaui batas. Dan makanlah makanan yang halal lagi baik dari apa yang Allah rezekikan kepadamu, dan bertaqwalah kepada Allah yang kamu beriman kepada-Nya"24. Berikut penjelasan tingkat kepuasan konsumsi barang halal-haram dengan pendekatan Indifference Curve.

24 Sri Wahyuni. 2013. Teori Konsumsi dan Produksi dalam Perspektif Ekonomi Islam. Jurnal Akuntabel. Volume 10 No. 1 Maret 2013, hal 75. 
Tingkat Kepuasan Konsumsi Barang Halal-Haram a)

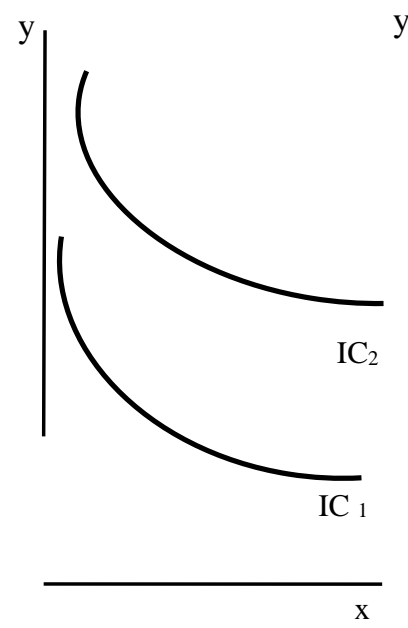

b)

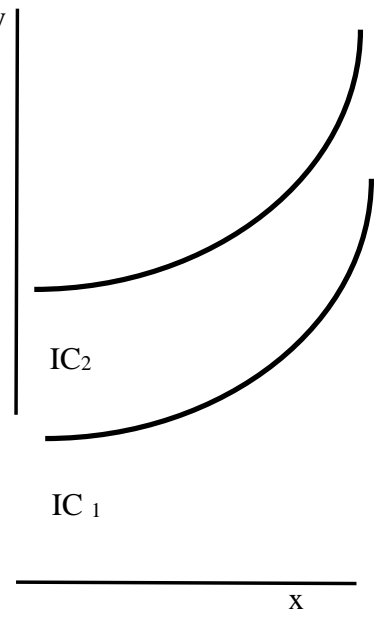

a) Tingkat kepuasan barang halal y dan halal $x$

b) Tingkat kepuasan barang halal y dan haram $x$

Semakin tinggi Indifference Curve (IC2) berarti semakin banyak barang yang dapat dikonsumsi yang berarti semakin tinggi tingkat kepuasan konsumen. Dalam Islam pun mengakui bahwa yang lebih banyak tentunya sesuai hukumnya, misal: yang halal- lebih baik. Dalil yang mendasari adalah " Orang beriman yang kuat lebih baik daripada orang beriman yang yang lemah" (HR).

Gambar di atas menunjukkan kombinasi dua barang halal yang dikonsumsi, semakin banyak barang dikonsumsi akan menghasilkan tingkat kepuasan yang lebih baik. Kombinasi dua barang tersebut dalam prinsip ekonomi Islam tidak menimbulkan masalah asalkan dibatasi oleh aturan yang Allah tetapkan (Al An'am (6):141). Dalam konsep Islam sangat penting adanya pemba- tasan yang tegas dalam perilaku konsumen barang halal dan haram.

Masalah tersebut dapat dijelaskan dengan pendekatan Indifference Curve. Jika kurva sebelah kiri diletakkan sebuah cermin maka akan menghasilkan kurva sebelah kanan. Kurva di atas menunjukkan semakin sedikit barang haram yang dikonsumsi maka semakin tinggi tingkat kepuasannya. Pergeseran tingkat kepuasan ke kiri atas menunjukkan semakin sedikit barang haram yang dikonsumsi dampaknya kombinasi konsumsi pun bergeser yakni semakin banyak barang halal dikonsumsi. Artinya semakin konsumen muslim mengurangi konsumsi barang haram dan memperbanyak konsumsi barang yang halal maka tingkat kepuasan semakin tinggi. Mengacu pada dalil di atas dan pendekatan Indifference Curve maka diharapkan perilaku konsumen muslim adalah mengurangi konsumsi barang haram dan lebih memperbanyak konsumsi barang halal, atau konsumen akan mencapai kepuasan tertinggi dengan meminimalisir barang haram.

Sekira 47\% - 65\% konsumen Indonesia mengalami penurunan pendapatan rumah tangga. Ini tentunya akan mempengaruhi besarnya konsumsi mereka. Karena besarnya konsumsi dipengaruhi oleh besarnya pendapatan. Di samping itu dalam teori konvensional mengakui bahwa keinginan untuk mencapai kepuasan ada batasnya, yakni keterbatasan anggaran (Budget Constraint). Hal ini bisa dijelaskan dengan pendekatan Indifference Curve dan Budget Line, dijelaskan dengan gambar kurva di bawah ini: 
Kepuasan maksimum (U) dan Budget y Line (B)

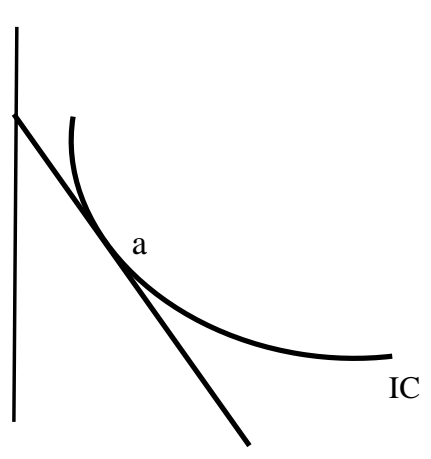

B

Kepuasan maksimum konsumen dapat dicapai bila terjadi pada titik singgung antara Indifference Curve tertinggi dengan Budget Line (titik a). Artinya berapa pun besar anggaran akan habis dikonsumsikan, maka akan tercapai kepuasan tertinggi.

Konsumsi Islam tentunya berbeda, konsumen akan berperilaku sesuai dengan dalildalil yang telah diungkapkan di atas. Ketika sudah terpenuhi kebutuhan dasarnya, walaupun kurva Indifference Curve tertinggi belum menyentuh Budget Line maka sudah terpenuhi kepuasan konsumsinya. Konsumen meyakini, apabila berperilaku ishraf, maka area konsumsinya akan bergeser pada konsumsi mubah bahkan haram. Ini artinya melanggar batasa-batasan syariah.

Bila belum menyentuh antara Indifference Curve dengan Budget Line, konsumen akan bisa memperbesar infaq atau tindakan menabung. Formula konsumsi ${ }^{25}$ menurut kerangka Islam berikut dapat menjelaskannya:

$$
\mathrm{Y}=(\mathrm{C}++\mathrm{Infaq})+\mathrm{S}
$$

25 Adiwarman Karim. 2010. Ekonomi Mikro Islami. Jakarta: PT. Raja Grafindo Persada, hal 90.
Merujuk dari Monzer Kahf (1981), dengan asumsi: (1) Islam dilaksanakan masyarakat; (2) Zakat hukumnya wajib; (3) Tidak ada riba dalam perekonomian; (4) Mudharabah merupakan wujud kegiatan perekonomian; (5) Pelaku ekonomi mempunyai perilaku memaksimalkan kemaslahahan.

Dari asumsi di atas, berarti $\mathrm{Y}$ merupakan Pendapatan Disposible yakni pendapatan yang siap dikonsumsi karena telah dikurangi oleh kewajiban membayar zakat. Perilaku konsumen menurut Islam diharapkan adalah tidak berlebihan dan tidak boros, sehingga ia masih dapat mengalokasikan pendapatannya untuk menafkahkan di jalan Allah, yakni Infaq. Semakin konsumen tidak mengejar kepuasan maksimum (want) atau hanya memenuhi kebutuhannya (need), maka konsumen akan memperbesar kesempatan membayar infaq. Dengan asumsi bahwa konsumen masih memiliki pendapatan, berikut penjelasan dengan kurva kepuasan maksimum dan garis anggaran:

Kepuasan maksimum (U) dan Budget Line (B) dalam Kerangka Islam

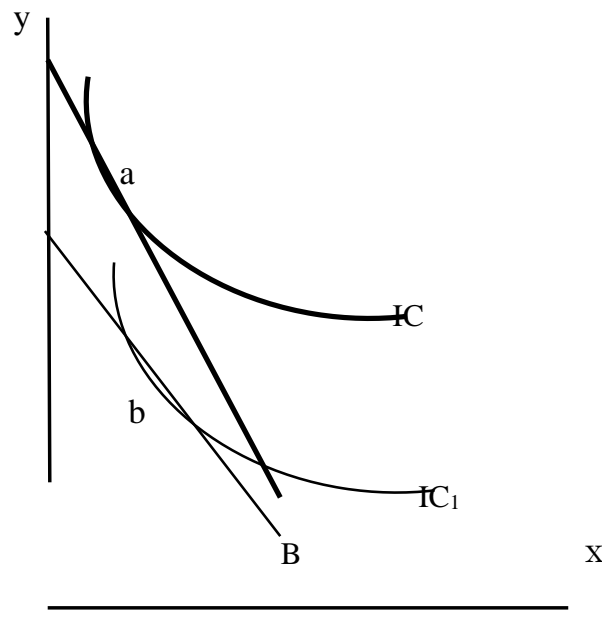

Titik a merupakan kepuasan maksimum yakni ketikan anggaran habis untuk konsumsi (IC) atau untuk memenuhi keinginan. 
Sedangkan, kepuasan dalam konsumsi menurut Islam adalah memenuhi kebutuhan. Jika asumsinya pada $\mathrm{IC}_{1}$, konsumen sudah terpenuhi kebutuhannya maka realisasi anggaran akan ada sisa. Dengan demikian sisa tersebut akan memperbesar kesempatan untuk membayar infaq sesuai dalam surah Al Baqarah (QS 2:219): “.....Dan mereka menanyakan kepadamu (tentang) apa yang (harus) mereka infakkan. Katakanlah, "Kelebihan (dari apa yang diperlukan)".

Pada titik b, konsumen Islami sudah meraih kepuasan tertinggi, karena memenuhi kepuasan di dunia dan akhirat. Kepuasan di dunia yakni terpenuhi keperluannya (kebutuhannya), sedangkan kepuasan di akhirat adalah teraihnya keselamatan (kemenangan) karena memenuhi ketentuan Allah seperti dalam Al Hadid (57):7: “... Maka orang-orang yang beriman di antara kamu dan menginfakkan (hartanya di jalan Allah) memperoleh pahala yang besar."

Dikatakan dengan istilah kesempatan untuk membayar infaq karena ini adalah sebuah pilihan. Pilihan lainnya, kosumen bisa melakukan tindakan menabung. Namun menabung untuk tujuan berjaga-jaga bukan untuk tujuan spekulasi. Spekulasi dilarang oleh Islam karena mengandung maisir sesuai surah $\mathrm{Al}$ Baqarah (2):219 dan $\mathrm{Al}$ Maidah (5):90-91.

Jika asumsinya konsumen tidak ada pendapatan, maka konsumen tetap melakukan konsumsi. Ini dapat ditunjukkan oleh persamaan konsumsi berikut:

$$
\mathrm{C}=\mathrm{a}+\mathrm{bY}
$$

Konsumsi jika tidak ada pendapatan adalah sebesar a, dan ini merupakan konsumsi untuk memenuhi kebutuhan yang sangat primer. Konsumsi tersebut dipenuhi oleh berbagai cara seperti, antara lain: menggunakan simpanan sebelumnya, program bantuan dari pemerintah, kepedulian dari keluarga serta sesama dan lain sebagainya.

Dari uraian di atas dapat dikatakan bahwa dalam kondisi pandemi Covid-19, konsumen Muslim yang terdampak karena penurunan pendapatan akan menghadapinya dengan relatif baik. Akan segera beradaptasi ketika permintaannya bergeser atau berubah akibat kondisi di atas.

Hal ini karena perilaku konsumsinya telah terlatih dan terbiasa berpedoman sesuai tuntunan agar tidak ishraf, tidak tabdzir serta halal sehingga diridhoi Allah SWT. Di samping itu sebagian konsumen tetap dapat menjalankan infaq, ini terbukti dengan adanya saling membantu atau tolong me-

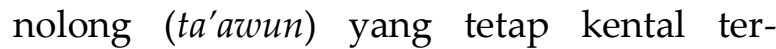
pelihara selama pandemi Covid-1926. Dapat dikatakan perilaku konsumen tetap dalam kerangka ajaran Islam, hingga teraih tujuan kosumsi yakni maslahah dalam rangka mencapai tujuan yang lebih tinggi yakni kemenangan di dunia dan akhirat.

\section{SIMPULAN}

Ekonomi Mikro Islam, dimana variabelvariabelnya tidak hanya dijadikan alat analisis atau landasan keputusan oleh berbagai pihak, namun juga memasukkan prinsip syariah sebagai landasannya. Konsumsi menurut Islam dapat dijelaskan melalui pendekatan-pendekatan teori konsumsi pada ekonomi mikro konvensional, perbedaannya konsumsi menurut Islam terdapat prinsip-prinsip dan batasan-batasan syariah. Tujuan konsumsi Islami adalah untuk

26 Talidah Putri Syafril. 2020. Tren Perilaku Menolong pada Situasi Pandemi COVID-19. Fakultas Ilmu Sosial dan Ilmu Politik Universitas Brawijaya. Diakses dari: https://fisip.ub.ac.id/, pada tanggal 21 Desember 2020, hal 1. 
memperoleh maslahah. Konsep efisiensi dalam ekonomi konvensional adalah memaksimumkan kepuasan keinginan (want), sedangkan dalam kerangka Islam memaksimumkan pemenuhan kebutuhan (need).

Konsumen Muslim yang terdampak pandemi Covid-19, akan menghadapinya dengan relatif baik. Segera menyesuaikan ketika permintaannya bergeser atau berubah akibat suatu kondisi. Karena perilaku konsumsinya telah terlatih dan terbiasa berpedoman pada tuntunan agar tidak ishraf, tidak tabdzir serta halal sehingga diridhoi Allah SWT. Sebagian konsumen tetap dapat menjalankan infaq, ditunjukkan dengan adanya ta'awun selama pandemi Covid-19. Sehingga dalam kegiatan kosumsi teraih tujuan yakni maslahah, dalam rangka mencapai tujuan yang lebih tinggi yakni kemenangan di dunia dan akhirat.

\section{REFERENSI}

\section{Buku, Jurnal dan Karya Ilmah:}

Hutauruk, Martinus Robert. 2020. Pengaruh Pandemi Covid-19 terhadap Faktor yang Menentukan Perilaku Konsumen untuk Membeli Barang Kebutuhan Pokok di Samarinda. Jurnal Riset Inossa Volume 2 Nomor 1 Tahun 2020.

Ihsan, Fadhel dkk. 2015. Stdi Analisis Pemikiran Muhammad Abdul Mannan tentang Konsep Konsumsi dalam Ekonomi Islam. Prosiding Penelitian SPeSIA 2015.

Irma, Ramadhani. 2008. Perilaku Konsumen Islami. Oiko $\sum$ Jurnal Manajemen Vol 1 No 1 2008, ISSN: 1979-4770.

Janwari, Yadi dkk. 2020. Ekonomi Islam sebagai Disiplin Ilmu. UIN Sunan Gunung Djati Bandung.

Karim, Adiwarman. 2010. Ekonomi Mikro Islami. Jakarta: PT. Raja Grafindo Persada.

Kohli, Sajal dkk. 2020. How COVID-19 is Changing Consumer Behavior-Now and Forever. Mc Kinsey \& Company. Diakses dari https://www.mckinsey. com/ pada tanggal 15 Desember 2020.

Lipsey, Richard G. dkk. 1995. Pengantar Mikro Ekonomi. Jakarta: Binarupa Aksara.

Mannan. 1997. Teori dan Praktik Ekonomi Islam. Yogyakarta: PT. Dana Bhakti Prima Yasa.

Muhammad. 2005. Ekonomi Mikro dalam Perspektif Islam. Yogyakarta: BPFE.

Suprihatin, Wiwik. 2020. Analisis Perilaku Konsumen Wisatawan Era Pandemi Covid-19 (Studi Kasus Pariwisata di Nusa Tenggara Barat). Jurnal Bestari Volume 01 Nomor. 01 Agustus 2020.

Syafril, Talidah Putri. 2020. Tren Perilaku Menolong pada Situasi Pandemi COVID-19. Fakultas Ilmu Sosial dan Ilmu Politik Universitas Brawijaya. Diakses dari: https://fisip.ub.ac.id/, pada tanggal 21 Desember 2020.

Wahyuni, Sri. 2013. Teori Konsumsi dan Produksi dalam Perspektif Ekonomi Islam. Jurnal Akuntabel. Volume 10 No. 1 Maret 2013. 
Internet:

A. Rafqie Muhamad Choerul. 2020. Pandemik Covid-19 dan Dampaknya Bagi Depresi Ekonomi Indonesia. Diakses dari https://www. kompasiana.com/ pada tanggal 4 April 2020.

Bank Indonesia. 2020. Perkembangan Terkini Perekonomian dan Langkah BI dalam Hadapi COVID-19 (26 Maret 2020). Diakses dari https://www.bi.go.id/ pada tanggal 20 April 2020.

GfK Digital Research. 2020. Ini Tren Perilaku Konsumen Pasca Krisis Covid-19. Diakses dari https://www. indotelko. com/ pada tanggal 14 Desember 2020.

Kemkes. 2020. Situasi Terkini Perkembangan Coronavirus Disease (COVID-19) 29 April 2020. Diakses dari https://covid19.kemkes.go.id pada tanggal 4 Mei 2020.

Lawi, Gloria F K. 2020. Begini Pergeseran Perilaku Konsumen Baru selama Pandemi Covid-19. Diakses dari https://ekonomi. bisnis.com/ pada tanggal 14 Desember 2020.

Ngabito, Annetly. 2020. Survei PwC: Pandemi Mengubah Perilaku Konsumen. Diakses dari https://www. pwc.com/id/ pada tanggal 14 Desember 2020.

Sirclo. 2020. Bagaimana Perubahan Pola Konsumsi Masyarakat Indonesia Selama Pandemi COVID-19? Diakses dari https://www.sirclo.com/ pada tanggal 15 Desember 2020. 